\title{
Sustainable Tourism in the Albanian Riviera - Cultural Routes Contibution in Sustainable Tourism in the Albanian Riviera
}

Sonia Joijc

Abstract

This article studies the potential impact of the cultural routes proposed in the Albanian Riviera case study on the development of sustainable tourism in the southern coast of Albania, focusing especially on the innovative cocreation of experience and narratives. Nowadays, in the field of cultural tourism, there is a similar shift away from static museums and monuments towards more interactive and intangible way of experiencing. Because of these new approaches, cultural tourists seek out the defining elements of the atmosphere of places even more than before. This knowledge empowers individuals not only to see or experience a place, but to live and breathe the very culture.

Keywords: Sustainable Tourism in the Albanian Riviera Cultural Routes Contibution in Sustainable Tourism in the Albanian Riviera

\section{Introduction}

Nowadays, tourism is one of the most important economical sources of Albania, especially for the southern Albanian Riviera. Even though the coastal region of Albania has been commonly recognized as the country's most valuable development asset since the 1990s, there are many unfavorable phenomena's that have continued to prevail during the transition to democracy, along with new unfavorable development trends such as unregulated urbanization, illegal building, sprawl development along the coast. All of the aforementioned factors have directly affected the cultural and natural heritage, frequently ignoring traditional urban/architectural patterns (World Bank 2015). ${ }^{1}$

The region of the Albanian Riviera begins south of the Llogara National Park, continuing along through the villages of Dhermi, Vuno, Jale, Himare, Borsh, Qeparo, Piqeras, Lukove. This entire area has been proclaimed as one of the 2012 Top Value Destination by Frommer', not only for its beautiful rocky beaches but also for its untold stories and great landscape (Frommers 2012). ${ }^{2}$

The Riviera features traditional Mediterranean villages, ancient castles, Orthodox churches, turquoise beaches, interesting mountain passes, seaside canyons, flowing rivers, amazing underwater fauna, caves, orange and lemon crops, and olive groves; quite the package in offering diverse and sustainable tourism.

\footnotetext{
1 Based on the report obtained from the Ministry of Urban Development, Albania Coastal Zone Development and Clean-up Program Environment and Social Safeguards Framework. 2011.

2 Source: http://www.frommers.com/micro/2011/top-destinations-2012/top-value-destination-albanian-riviera.html
} 


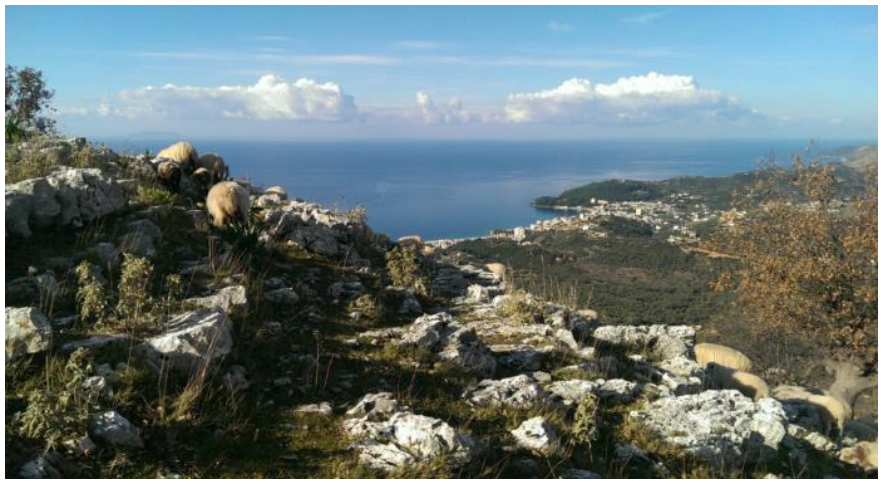

Fig. 1 Albanian Riviera Landscape, Himara. Source: Sonia Jojic

Due to Albania's long isolation and the urge of its inhabitants to migrate after the ' 90 s, there was a tendency to leave the villages located along the abandoned coast for either Greece or Italy. Yet, for the past 10 years and still continuing, many immigrants are coming back due to the economic crisis affecting Europe, investing their capital earned abroad in either building hotels or estates, without firstly evaluating the current state of the place and surroundings. This neglect directly affects the cultural and natural heritage of the historic villages by destroying the picturesque scene and polluting it.

It is essential to emphasize that tourism in the Albanian Riviera, aside from all the natural diversity offered, is greatly focused on beach retreats during the summer season from June - August with no other options for the rest of the year. While beaches can be fully packed during summer season, there is plenty of space and peace during low season. Sadly, the issues of the past decade's poorly planned development have ruined many once-charming coastal villages. This trend is still directly fostered by local management issues such as poor road and public utilities infrastructure, unregulated waste disposal, illegal construction etc.

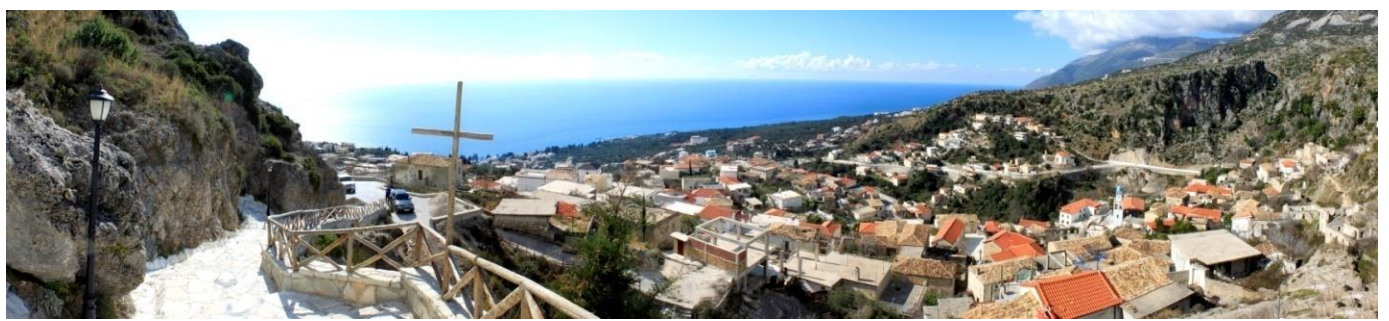

Fig. 2 Village of Dhermi. Source: Sonia Jojic

In addition to the attempts of the previous government and the World Bank in disposing managing alternative projects such as the Integrated Coastal Zone Management and Clean-up Project, focused on supporting infrastructure for the improvement of environmental and sanitary conditions essential for the long term coastal development and tourism of the Albanian Riviera, there is still the need to come up with alternative ways for the future development of the southern coast, better hosting alternative tourism, without affecting the environment and the unique picturesque landscape of the Albanian Riviera. (World Bank 2015) 


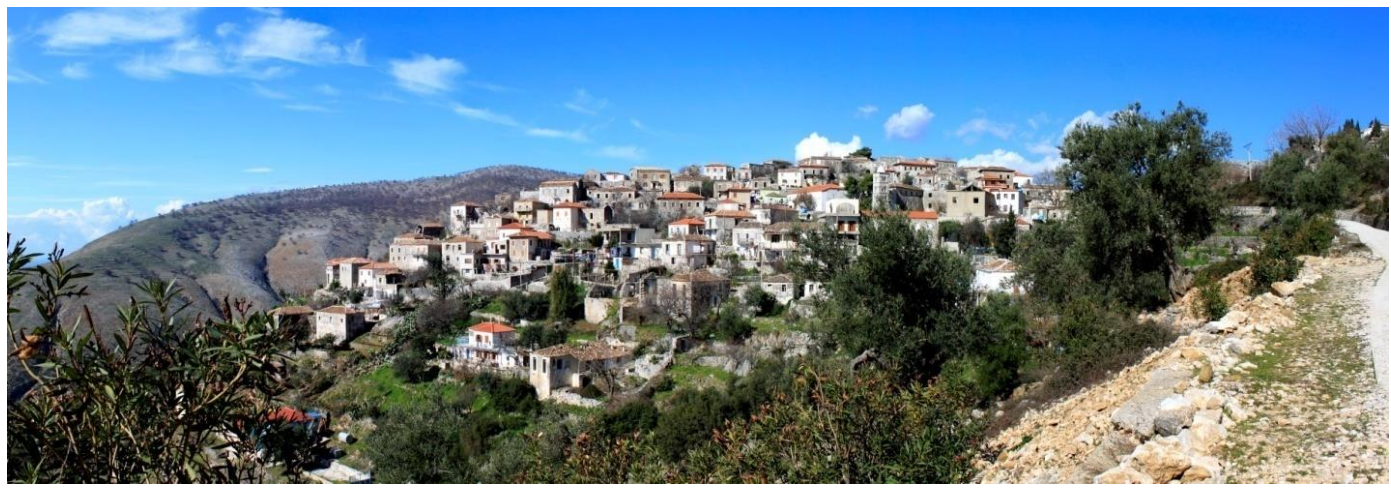

Fig. 3 Village of Upper Qeparo. Source: Sonia Jojic

Sustainable tourism categories should be introduced to the Albanian culture, not only because of the long-term economic gain and inclusion of SME - small and medium-size enterprises, but also for the proper use of its natural, cultural and historical potentials in branding Albania in a better and more sustainable way. The European commission has been fostering the concept of cultural tourism since 1987, encouraging methods that have impacted many countries in terms of creating better sustainable tourism in Europe. There are many countries that have fully embraced it but the southeastern part of the Balkans is still falling behind in creating sustainable tourism and branding cultural tourism / routes. (UNTWO, Sustainable Tourism for Development, Enhancing capacities for Sustainable Tourism fordevelopment in developing countries 2013) Cultural tourism / routes can be the perfect solution for preventing the continued uncontrolled development in the Albanian Riviera, noting cultural/natural heritage as the main actors in fostering solutions regarding the area's alterative tourism.

\section{Council of Europe - The Cultural Routes Programme}

Cultural tourism is essentially about journeys. Not just because tourists by definition travel to experience culture, but also because culture itself is a journey - a voyage of discovery and self-realization. Cultural Tourism searches for and uses the local and defining elements of a place which enables visitors not only to see or experience a place, but to live and dwell in the culture itself.

Not only does cultural tourism develop a narrative of the place in which both locals and tourists dwell, but it also develops narratives about the individual tourists who go through and experience interculturality in those places. The narrative of tourism therefore links place and journey, local and global, dwelling and mobility, host and guest. (WTO 2014)

In 1987, the Council of Europe launched The Cultural Routes programme. Its objectives were to demonstrate how the heritage of different countries and cultures of Europe contributes to a shared cultural heritage, putting into practice the fundamental principles of the Council of Europe: human rights, cultural democracy, cultural diversity and identity, dialogue, mutual exchange and enrichment across boundaries and centuries. The Committee of Ministers of the Council of Europe adopted Resolution CM/Res(2010)53 in December 2010, establishing an Enlarged Partial Agreement (EPA) to enable closer co-operation between states mostly interested in the development of Cultural Routes. (Council of Europe 2015) ${ }^{1}$

The representatives taking part in this Committee were the Ministers of Austria, Azerbaijan, Bulgaria, Cyprus, France, Greece, Italy, Luxembourg, Montenegro, Portugal, Russian Federation, Slovenia and Spain, outlined the Policy-making and standard setting of the established EPA2 (Khovanova-Rubicondo 2013)

The EPA states that: the expertise of the European Cultural Routes Institute shall provide advice and expert assistance for the development, implementation, evaluation and promotion of Cultural Routes.

\footnotetext{
${ }^{1}$ Information obtained from official website of Council of Europe; "Partial Agreement on Cultural Routes"; http://www.coe.int/t/dg4/cultureheritage/culture/routes/default_en.asp

2 Enlarged Partial Agreement 2010; the Committee of Ministers of Councils of Europe.
} 
This involved expertise on: setting up and functioning of project networks and organizations and the development of co-operation agreements; research on the historical background of the routes and the development of the cultural and educational content and activities of the Cultural Routes; development of a sustainable tourist offer based on the Cultural Routes, thus contributing to the economic well-being of regions; preparation and implementation of financing and promotion strategies; training and capacity building for Cultural Routes operators, in particular in relation to the Council of Europe and other international standards in the field of heritage and culture, as well as standards of professional practice in the field of tourism; promotion, visibility and all other aspects related to compliance with the Council of Europe standards.

Furthermore, the EPA is obliged to support networking and exchange between Cultural Routes operators and other partners in the field of cultural tourism, specifically: the development of a common vision and strategy for cultural routes as touristic products; the development of partnerships to increase the resources available for cultural tourism in Europe; the identification and dissemination of good practice.

EPA shall develop further methodologies for the promotion of cross border cultural tourism.

In September 2010, the European Commission and the Council of Europe launched a study focusing on European Cultural Routes impact on SMEs ${ }^{1}$ innovation, competitiveness, and clustering. The aim of the study was to provide insights on the effects produced by the CoE Cultural Routes Programme on SMEs performance, network and cluster development. Moreover, the study also sought to observe the potentials of the Cultural Routes in promoting sustainable and quality tourism in Europe, increase European identity, disseminating the richness of European cultures and promoting intercultural dialogue and mutual understanding. (Khovanova-Rubicondo 2013)

Of particular importance for Albania is that the study analyzes how much the Cultural Routes networks can affect and benefit SMEs, especially in less-known destinations, where the local culture and heritage are the main resource for development, and how SMEs' clusters can create a solid basis for promoting the region as "the world's No 1 tourist destination". ${ }^{2}$ Thus the idea of cultural routes for Albania, but especially for the Albanian Riviera can create potential clusters and co-operation for the entire region of the Balkans. This will give more potential in controlled development and stable economy growth for tourism in Albania.

\section{Adriatic - Ionian Basin States involved in Cultural Routes programme}

Promotion of cultural tourism is a logical next step in developing Cultural Routes. For years now, the European Commission has especially focused on encouraging countries in fostering Cultural Routes for a more sustainable tourism. The uniqueness of this type of tourism builds on the individuality and authenticity of remote destinations, local knowledge, skills, heritage and traditions. Over the past years most of the South Eastern states in the Adriatic - Ionian Basin have been and are still participating in the Cultural Routes programmes. These countries include Slovenia, Croatia, Bosnia and Herzegovina, Montenegro, Albania and Greece. However, in all the different cultural routes that the majority of these countries partake in Albania is involved in only one of them "The Routes of the Olive Tree", which does not fall under the category of cultural routes, but that of gastronomic tourism. If we take a look at all the Cultural Routes from the previously listed states, we can ascertain that; Slovenia is currently participating in the following Cultural Routes activities and present projects:

- Saint Martin de Tours: a great European figure, a symbol of sharing

- The Routes of the Olive Tree

- Transromanica

Croatia Council of Europe Cultural Routes:

- Saint Martin de Tours: a great European figure, a symbol of sharing

- The Jewish Heritage Routes

\footnotetext{
1 SME abbreviation for "small and medium-sized enterprises"

${ }^{2}$ Chapter 6, Increasing attractiveness of the lesser known European destinations via the Council of Europe Cultural Routes programme; Impact of European Cultural Routes on SMEs' innovation and competitiveness, published by the Council of Europe, 2010
} 
- The Routes of the Olive Tree

Bosnia and Herzegovina Council of Europe Cultural Routes:

- The Routes of the Olive Tree

Montenegro Council of Europe Cultural Routes: None

Albania Council of Europe Cultural Routes:

- The Routes of the Olive Tree

Greece Council of Europe Cultural Route:

- The European Route of Jewish Heritage

- European Cemeteries Route

- The Routes of the Olive Tree

- The Phoenicians' Routes

- The Iter Vitis Route

While Slovenia, Croatia and Greece are more developed countries in terms of tourism, Bosnia Herzegovina, Montenegro and Albania fall short in terms of their participation in the Cultural Routes programme. (Council of Europe, Enlarged Partial Agreement on Cultural Routes 2014)

According to the European Commission's concept of Cultural Routes in Europe, the most urgent issues that countries like Albania, Montenegro, Bosnia Herzegovina need to address includes the development of better:

- transnational connectivity of the Cultural Routes network;

- co-ordination of the development and promotional strategies of the Cultural Routes at a European level;

- brand image and marketing strategies;

- quality and sustainable tourism standards development/implementation;

- human and financial resources of the Routes;

- expertise in the management of the networks;

- exchange of good practices; and

- network management and performance evaluation tools, all issues that at this stage Albania is lacking, and especially the Albanian Riviera where there is the need to develop a proper strategic plan in branding the area through sustainable tourism. (Khovanova-Rubicondo 2013)

\section{Developing Cultural Routes for the Albanian Riviera}

Taking in consideration all the villages extended along the southern coast of Albania and the historic background of the southern villages linked to Greece, there is a lot of potential in fostering more sustainable tourism. Cultural tourism and especially cultural routes identified in the area can encourage complicity in increasing linkages between suppliers and consumers; creating contact with local culture; and emphasizing the everyday intangible heritage. On the other hand, there is the need to shift towards promoting events as means of advertising places as more creative spaces for originality and user-generated content. The importance of cultural tourism is the development of a narrative about a place in which both locals and tourists dwell, but also its ability to develops narratives about the individual tourists who go through and 
experience interculturality in those places. The narrative of tourism therefore links place and journey, local and global, dwelling and mobility, host and guest. ${ }^{1}$ (International Tourism Consulting Group 2013)

In the case study of the Albanian Riviera, the research focused on promoting the cultural tourism of the area through different interventions would have a positive effect through the fostering of economic growth of the southern Mediterranean villages. The entire Riviera was segmented in five main potential tourism targets, such as Cultural Tourism; Alternative Tourism; City Tourism; Family Tourism, and Eco Tourism, in the effort of reactivating the whole area.

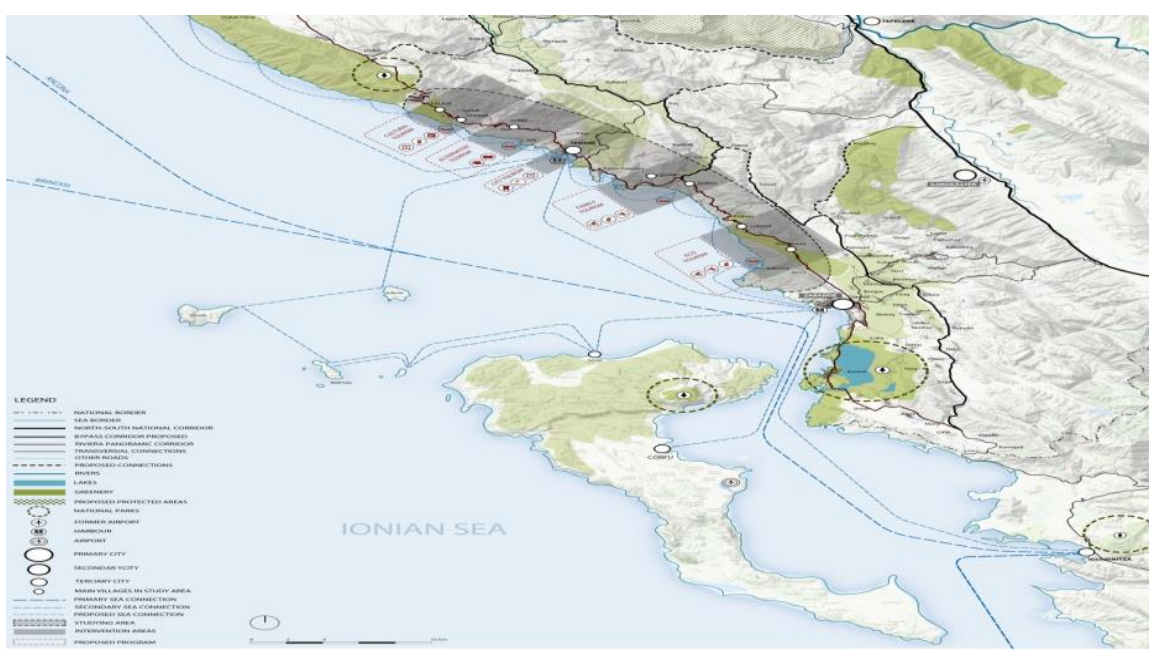

Fig. 4 Segmentation of Tourism potential targets.

The objectives and challenges highlighted during the research were the importance of tourism in the Riviera; its environmental and cultural heritage including mountains and coastal landscapes; villages and local communities; traditions, and identities. Furthermore, the study aimed to develop a sustainable growth based on sustainable tourism which means a low-impact development of infrastructures and facilities that still respects local people and travelers, cultural heritage and the environment, thus further promoting the concept of cultural routes in the area.

The cultural heritage found in the Albanian Riviera is one of the most crucial elements in building up and promoting Cultural Routes in the area. As previously mentioned, the only countries currently participating in a wider range of activities and present projects focusing on Cultural Routes are Slovenia, Croatia, and Greece, with diverse cultural routes programs. However, due to the historic background of the villages in connection to Greece and its culture, theirs is an optional gap in linking continuous cultural routes. The study conducted by POLIS University and the University of Ferrara attempted precisely to create and promote different activities in the Riviera for the course of the entire year, not only the summer season as it still happens; therefore, the yearly activities calendar of the area matches with the current focus of the Cultural Routes programme, such as: New ways/path of pilgrimage; Maritime and trade routes; cultural routes of industrial / military heritage; landscape and civilization; European routes of historical towns (Khovanova-Rubicondo 2013)22.

The emphasis should not only be placed on the beautiful coastline that the Riviera has but also on cultural tourism as one of the most important components for better identifying the culture of a place. For instance, the Albanian Riviera extends between two major natural and cultural points, the "Llogara National Park" and the "Butrinti National Park", where Mediterranean villages full of culture and tradition enrich the area even more. Along this segment, we can identify some major cultural routes.

\footnotetext{
${ }^{1}$ Cultural Routes Trends outlined by UNWTO World Tourism Organization, in their 2014 Regional Report Volume III, "Working Together in Europe - A Shared Leadership" Pg 99, 2014

2 Information obtained from "Impact of European Cultural Routes on SMEs' innovation and competitiveness" from the European Commission publication, 2007 - 2013; pg 17-18.
} 


\section{Cultural Route 1: "Caesar's Pass"}

In addition to the breathtaking scenery and the diverse flora and fauna, the Llogara national park may also play a major role in hosting different cultural routes beginning from the Llogara National Park, "Caesar's Pass". There is evidence that in $48 \mathrm{BC}$, during his pursuit of Pompey, Julius Caesar set foot and rested his legion at Palase (Koci 2006). He continued onto Llogara Pass in a place later named Caesar's Pass (Koci 2006). "Caesar's Pass" can be a highly profitable cultural route not only for Albania but also the neighbored countries, hosting pedestrian and maritime paths of the villages from Palasa - Dhermi, strengthening scenic routes and enhancing slow mobility. (National Tourism Agency 2015)

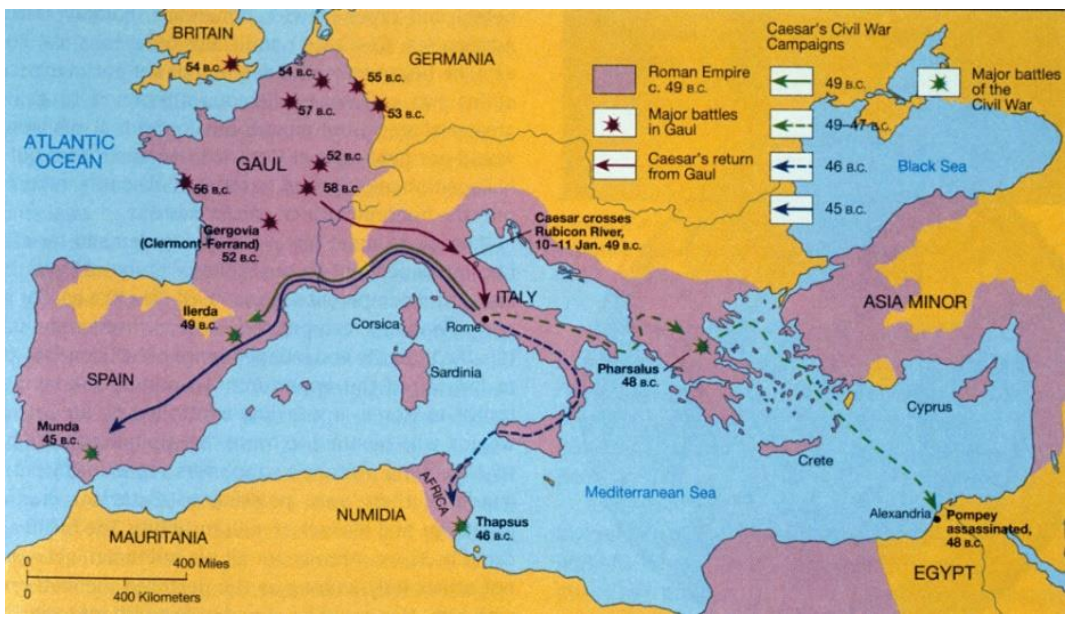

Fig. 5. Map Showing Julius Caesar's Military Career in $49-47$ B. C passing through south of Albania during his pursuit of Pompey. Source: University of Massachusetts Boston, http://www. faculty. umb. edu/gary_zabel/Courses/Phil\%2010808/Rome\%20-\%20Maps. htm

\section{Cultural Route 2: "Religious Cultural Routes"}

Additionally, the town of Dhermi, besides its beautiful beaches and resort, can also host annual pilgrimage cultural routes events due to numerous number of monasteries and churches such as: the Monastery of Shën Maria, the Church of Shën Todhri, the Church of the Ipapandia and the Church of Shën Mitri with its frescos dating from the 12th -14th centuries. Furthermore, the pilgrimage cultural route can also extend to Vuno (the Church of Shën Spiridhoni, built in 1778, the Church of Mesodhia with paintings from 1783), Himara (the Church of Shën Maria e Athalit, the Church of Cassiopeia, the Church of All Saints) and Qeparo (the Monastery of Shën Dhimitri) (Koci 2006) thus connecting religious cultural routes with Greece. (Koci 2006)

\section{Cultural Route 3: "Chaonians Cultural Route"}

The Chaonians were an ancient Greek tribe that inhabited the region of Epirus located in the northwestern part of modern Greece and southern Albania. Here, both Himara (Chimaira) ${ }^{1}$ and Butrinti (Buthrotum) played a major role. The Chaonians Cultural route could connecting the town of Himara Albania (Chimaira) with Igoumenitsa (Thesproti). (Koci 2006)

Fig 5. Left - Epirus in antiquity. Source: Hellenica. de, http://www. hellenica. de/Griechenland/Ort/EpirusOldMap.jpg

Fig. 6. Right-Map showing Kemera and Bouthroton towns within the region of Epirus. Two major centers of the Greek tribe of the Chaonians. Source: Archeological Map of Albania

\footnotetext{
1 The town of Himarë is believed to have been founded as Xípaıpa, (Chimaira, hence the name Himara) by the Chaonians as a trading outpost on the Chaonian shore. Data obtained from: https://en.wikipedia.org/wiki/Himar\%C3\%AB\#cite_note-Hansen-17
} 

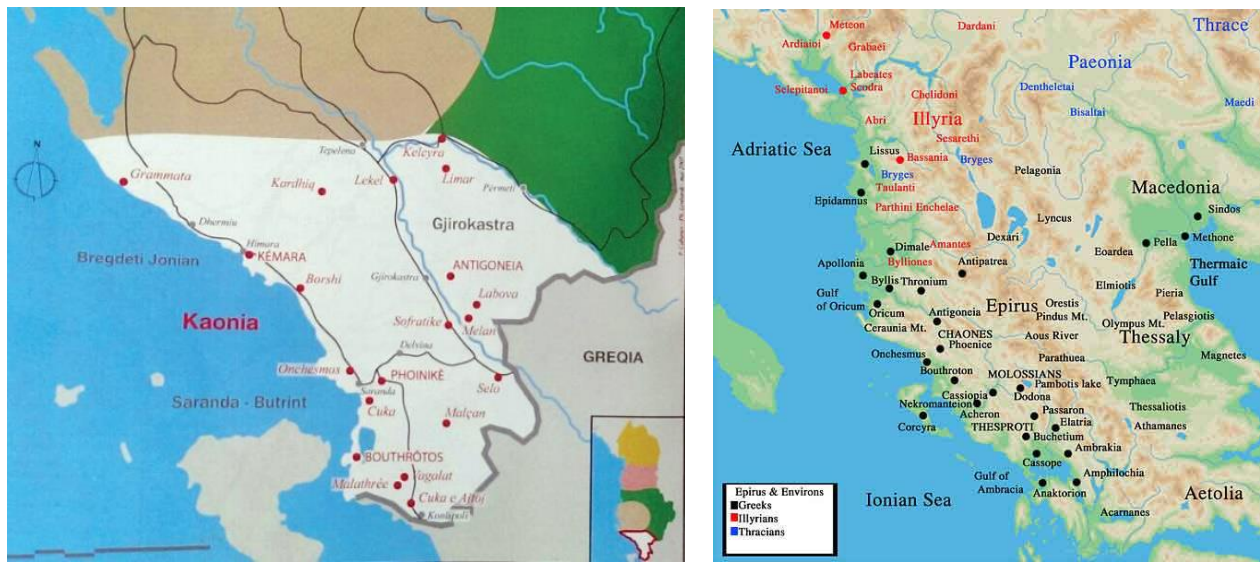

Many countries in Europe are key cultural touristic destinations, with a great number of major cultural sites. However, Albania stands at a great distance from Italy or Greece in terms of cultural sites and routes, specifically from a management point of view. According to European Commission data obtained from PIKx (2009), there was a $5 \%$ drop in the number of city visitors (usually closely related to cultural tourism), compared with a $20 \%$ drop in touring holidays and rural tourism, and a $15 \%$ fall in mountain recreation in 20091. (International Tourism Consulting Group 2013). These statistics indicated that despite the study's suggestions carried out in the Albanian Riviera, there is still a need for implementing new trends of cultural tourism, such as creative tourism; educational tourism; gastronomic tourism; religious tourism; spiritual and holistic tourism; wellness and spa tourism; cultural volunteer tourism; roots of migrant tourism. All new cultural tourism trends that the Albanian Riviera can possibly host and further develop for a better sustainable tourism. The above suggested examples of potential Cultural Routes match the minimal interventions done to the area. In the case of the Albanian Rivera, the study focuses on sustainable growth based on a sustainable tourism, which means a low-impact development of infrastructures and facilities for a tourism which will respect both local people and travelers, foster cultural tourism by its cultural heritage and the environment. Moreover, the study also focuses on further rebranding the area by initiating the inclusion of a yearly calendar where the concepts of creative, gastronomic, and religious tourism can attract visitors all over the year.

\section{The possible benefits of Cultural Routes for the Albanian Riviera.}

Firstly, by participating in the "The Enlarged Partial Agreement on Cultural Routes", Albania will establish and reinforce the potential impact of Cultural Routes in terms of cultural co-operation. Secondly, this program will develop sustainable territorial development and social cohesion not only in the Albanian Riviera area, but also in other potential areas of the country; giving particular attention to the themes of symbolic importance for European unity. It will help encourage local people value their history, culture and values, and most importantly discover less well-known destinations. Thirdly, it will help strengthen the democratic dimension of cultural exchange and tourism through the involvement of professional networks and associations, local and regional authorities, universities and professional organizations. Most importantly, cultural routes programs contribute to the preservation of a diverse heritage through theme-based and alternative tourist itineraries and cultural projects for a country like Albania.

As previously mentioned, Albania is currently participating in "The Routes of the Olive Tree", in which countries like Albania, Algeria, Bosnia-Herzegovina, Cyprus, Croatia, Egypt, France, Greece, Italy, Jordan, Lebanon, Libya, Malta, Morocco, Portugal, Serbia, Slovenia, Spain, Syria, Tunisia, Turkey share "The presence of the olive tree that has marked not only the landscape but also the everyday lives of the Mediterranean peoples. A mythical and sacred tree, associated with their rites and customs and has influenced their ways of life, creating a specific ancient civilization, the "olive tree civilization". 2Inaugurated in 1998, and organized by the highly dynamic Euro Mediterranean Olive Tree Cultural Foundation based in

\footnotetext{
${ }_{1}^{1}$ Data's obtained from the International Tourism Consulting group for the European Commission in 2009.

2 "The Route of Olive Tree", The Council of Europe Cultural Routes": 2005

http://www.coe.int/t/dg4/cultureheritage/culture/routes/olive_en.asp
} 
Messenia (Greece) comprising a wide range of institutions, organizations, universities and Chambers of Commerce in Mediterranean and European countries. This can be referred as the perfect example in how to managing cultural roots and its main actors for the Albanian Riviera. (Council of Europe, The Routes of the Olive Tree 2014)

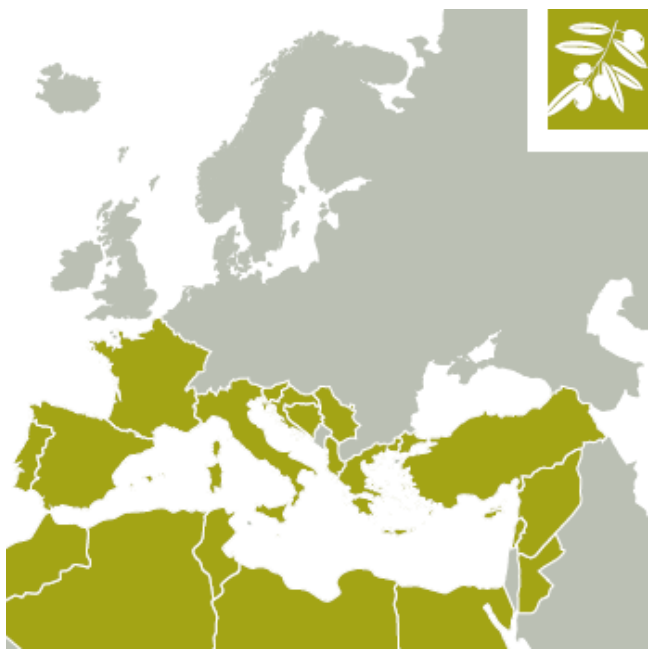

Fig 7. Countries involved in The Routes of the Olive Tree Programme. Source: Council of Europe, http://www. coe. int/t/dg4/cultureheritage/culture/routes/olive_en. asp

\section{Conclusion}

Albania is still new to the concept of sustainable tourism and especially cultural tourism routes. Tourism, one of the most important economical sources for Albania, especially for the southern Albanian Riviera, commonly recognized as the country's most valuable development asset since the 1990s, has been affected by many unfavorable phenomena that continued to prevail during the transition to democracy, along with new unfavorable developmental trends, such as unregulated urbanization, illegal building, sprawl development along the coast, directly affecting cultural and natural heritage by frequently ignoring traditional urban/architectural patterns of the southern villages.

This paper explored the suggested alternative tourism categories that can be introduced to the Albanian culture, not only for long-term economic gain, but also the inclusion of SME - small and medium-size enterprises. It emphasizes the concept and methods of cultural routes, a concept promoted by the European commission since 1987, one that should be fully embraced by the southeastern part of the Balkans in order to create sustainable tourism and brand cultural tourism / routes. A concept that may be the perfect solution for further prohibiting the continuation of uncontrolled development in the Albanian Riviera noting cultural/natural heritage as main actors in fostering alterative tourism solution for the area.

The role of the government, however, is much needed in providing basic infrastructure and regulations, easing the process of sustainable development for tourism purposes. The studies carried out at Polis University and Ferrara can further influence the process of policies aiming to promote area, even from an economic development point of view.

\section{Bibliography}

[1] Council of Europe, CE. Enlarged Partial Agreement on Cultural Routes. 2014. http://www. coe. int/t/dg4/cultureheritage/culture/Routes/Default_en. asp (accessed May 15, 2015).

[2] The Routes of the Olive Tree. 2014. http://www. coe. int/t/dg4/cultureheritage/culture/Routes/olive_en. asp (accessed June 3, 2015). 
[3] International Tourism Consulting Group, IPK. International Tourism Consulting Group. 2013. http://www. ipkinternational. com/en/company-profile/about-us/ (accessed May 20, 2015).

[4] Khovanova-Rubicondo, Kseniya. Impact of European Cultural Routes on SMEs' innovation. The study is financed under the Competitiveness and Innovation Framework Programme (CIP), Council of Europe, 2013.

[5] Koci, Jani. Himara, Arkeologji Histori Kulture Himara sot. Tirana: Gent-Grafik, 2006.

[6] Korkuti, Muzafer, Apollon Brace, and Neritan Ceka. Archeological Map of Albania. Tirana: Klosi \& Benzenberg, 2008.

[7] National Tourism Agency. Travel Discover Itineraries all over Albania. Tirane, June 23, 2015.

[8] TREE", CULTURAL FOUNDATION "THE ROUTES OF THE OLIVE. "THE ROUTES OF THE OLIVE TREE. 2014. http://www. olivetreeroute. gr/en/index_en. php (accessed May 23, 2015).

[9] UNTWO. Sustainable Tourism for Development, Enhancing capacities for Sustainable Tourism fordevelopment in developing countries. Madrid: UNTWO, 2013.

[10] UNTWO. UNTWO, Toursim Highlights. Toursim Report, Spain: UNTWO, 2014.

[11] World Bank, IBRD-IDA. "RESTRUCTURING PAPER ON A PROPOSED PROJECT RESTRUCTURING OF INTEGRATED COASTAL ZONE MANAGEMENT \& CLEAN-UP PROJECT. " Integrated Coastal Zone Management \& Clean-Up Project. 2015. http://www. worldbank. org/projects/P086807/integrated-coastalzone-management-clean-up-project-apl-1 ?lang=en (accessed June 2, 2015).

[12] WTO. Working Together in Europe A Shared Leadership. AM Regional Report: Volume three, Spain: WTO World Tourism Organization, 2014. 